\title{
The concept of 'internal judicial independence' in the case law of the European Court of Human Rights
}

\author{
Joost Sillen*
}

Internal judicial independence as a new element of the case law of the Strasbourg Court on Article 6 of the European Convention on Human Rights - The Court has only found violations of internal judicial independence in cases against former communist countries - Relevance of the case law for other member states of the Council of Europe - Internal judicial independence as part of the requirement of an impartial tribunal? - Importance of the independence of the individual judge

\section{INTRODUCTION}

The concept of internal judicial independence is intended to protect judges from undue pressure from within the judiciary. The concept was first mentioned in international soft law and in professional standards in the early 1980s. ${ }^{1}$ Around the turn of the millennium, the concept became more widespread. ${ }^{2}$ In 1999 it was included in the Universal Charter of the Judge ${ }^{3}$ and in 2007 in the Bangalore Principles of Judicial Conduct. ${ }^{4}$ In 2008, the Mount Scopus International Standards of Judicial Independence followed suit. ${ }^{5}$ In 2010 it received recognition in the Magna Carta of Judges and in the influential Recommendations of the

* Dr. J.J.J. Sillen is Associate Professor of Constitutional and Administrative Law at Radboud University, Nijmegen, Netherlands; email j.sillen@jur.ru.nl. I am grateful to the anonymous reviewers for their comments and suggestions. The usual disclaimers apply.

${ }^{1}$ Art. 47 of the Minimum standards of judicial independence of the International Bar Association (1982); Art. 2.03 of the Montreal Universal Declaration on the Independence of Justice (1983).

${ }^{2}$ I do not address domestic law in this article.

${ }^{3}$ Art. 2 IAJ of the Universal Charter of the Judge (Central Council of the International Association of Judges, 1999).

${ }^{4}$ Art. 1.4 of the Bangalore Principles of Judicial Conduct (2007).

${ }^{5}$ Art. 9 of the Mount Scopus International Standards of Judicial Independence (International Association of Judicial Independence and World Peace, 2008) 
Committee of Ministers of the Council of Europe. ${ }^{6}$ The European Court of Human Rights acknowledged this aspect of judicial independence explicitly for the first time in 2009 after it had done so implicitly as early as 2000. Although the acknowledgement of internal judicial independence by the Strasbourg Court fits in with this international trend, it also marks a turning point, as it was the first time the concept was acknowledged by an international tribunal whose judgments are binding on states. ${ }^{7}$

The recognition of the concept of internal judicial independence by the Strasbourg Court also signalled a clear turning point for the Court itself. Previously, it viewed judicial independence almost exclusively from a separation of powers perspective. ${ }^{8}$ This approach was based on the idea of an independent judiciary as a necessary safeguard against the legislative and executive branches. The reasoning was that to fulfil this safeguarding function, it was imperative for the judiciary to be separated from the other two branches of government. Especially after World War II, there was a growing awareness that such a separation was necessary. The Universal Declaration of Human Rights confirmed this; the drafters, in 1948, included the right to 'an independent [...] tribunal'. 'The Declaration inspired the drafters of the European Convention on Human Rights (the Convention) to incorporate a similar right in Article 6 of the Convention. ${ }^{10}$ In the last quarter of the 20th century, the Strasbourg Court interpreted Article 6 in an increasingly stringent manner. In numerous judgments, it stated that 'the concept of separation of powers between the executive and the judiciary ... has assumed growing importance in the case-law of the Court. ${ }^{11}$ Although the Strasbourg Court consistently stressed that it did not prescribe a specific theory of

${ }^{6}$ Art. 2 of the Magna Carta of Judges (Consultative Council of European Judges, 2010); Recommendation 22-25 of CM/Rec(2010)12 of the Committee of Ministers [of the Council of Europe] to member states on judges: independence, efficiency and responsibilities (2010).

${ }^{7}$ Art. 46 of the Convention. However, the Strasbourg Court is meanwhile not the only international court, whose judgments are binding on the states, that acknowledges the concept of internal judicial independence. The Inter-American Court of Human Rights has followed its example. See e.g. Inter-Am. Ct. H.R. 23 August 2013, Supreme Court of Justice (Quintana Coella et al.) v Ecuador, paras. 49-51 ('the internal aspect [of judicial independence, JS] protects the judge as an individual even from the rest of the judicial system').

${ }^{8}$ There are exceptions to this rule. In some cases, the Court has also stated that judicial independence refers to the independence of the parties to proceedings. See e.g. ECtHR 16 July 1971, Case No. 2614/65, Ringeisen v Austria, para. 95. In the literature on the Court's case law, however, the separation of powers perspective dominates.

${ }^{9}$ Art. 10 of the Universal Declaration of Human Rights.

${ }^{10}$ See the preamble to the Convention.

${ }^{11}$ E.g. ECtHR 28 May 2002, Case No. 46 295/99, Stafford v UK, para. 78; ECtHR 6 May 2003, Case No. 39 343/98, 39 651/98, 43 147/98 and 46 664/99, Kleyn et al. v The Netherlands, para. 193; ECtHR 22 June 2004, Case no. 47 221/99, Pabla Ky v Finland, para. 29; ECtHR 6 November 2018, Case No. 55391/13, 57728/13 and 74041/13, Ramos Nunes de Carvalho e Sáv Portugal, para. 
separation of powers, its case law nonetheless became a driving force in perfecting the separation of the judiciary from, most importantly, the executive branch. ${ }^{12}$ The idea that the Convention should also protect judges against pressure from judges and other judicial officials within the judiciary went beyond this separation of powers perspective. This stemmed from the idea that the separation of powers itself does not sufficiently guarantee the independent administration of justice. Instead, it is also necessary that the individual judge hold a sufficiently autonomous position within the judiciary.

Since 2000, the Strasbourg Court has found a violation of internal judicial independence in 14 cases, with judgments issued against a limited number of countries in Eastern Europe, namely Croatia, Hungary, Lithuania, Romania, Russia, Slovakia and Ukraine. Their Communist past can explain this geographical concentration. Two circumstances in these countries tend to increase the chance of violations of internal judicial independence occurring. First, they lack a longstanding, deeply engrained judicial culture that values the autonomy of the individual judge. During Communist rule, which lasted until the late 1980s in these countries, there was no independent judiciary. On the contrary, there were close ties between the Communist Party and the judiciary. The fact that the courts were organised in a hierarchical and authoritarian manner further reduced the autonomy of individual judges. ${ }^{13}$ After the fall of the Communist regimes, and notwithstanding the profound democratic developments in these countries, aspects of this judicial culture remained entrenched. ${ }^{14}$ Second, the way in which the judiciary in these countries was organised after the fall of the Berlin Wall in 1989 enhanced the consequences of the absence of a culture of autonomy of individual judges. At the time, many of the former Communist countries opted for a model of judicial self-government. This choice was not entirely voluntary. To become a member of the European Union, which many of these countries aspired to, they had to meet the Copenhagen criteria set out in 1993 by the European

144. See D. Kosař, 'Policing Separation of Powers: A New Role for the European Court of Human Rights?', 8(1) EuConst (2012) p. 33.

${ }^{12}$ The development of the case law of the Strasbourg Court described above is sketched in broad strokes. The reality is, of course, more nuanced. For example, although the ECtHR has emphasised the importance of the judiciary being separate from the other government branches, it has never expressed any doubts regarding the Appellate Committee of the House Lords. Nevertheless, the Strasbourg case law on Art. 6 of the Convention 'strengthened the argument' for abolishment of the Appellate Committee (David Hope, 'The Reform of the House of Lords', 60(2) Revue Internationale de Droit Comparé (2008) p. 260).

${ }^{13}$ D. Kosař, Perils of Judicial Self-Government in Transitional Societies (Cambridge University Press 2017) p. 132-133, with further references.

${ }^{14}$ Kosař, supra n. 13, p. 3-4 and 132-134. See also A. Nußberger, 'Judicial Reforms in Post-Soviet Countries - Good Intentions with Flawed Results?', in A. Seibert-Fohr (eds.), Judicial Independence in Transition (Heidelberg: Springer 2012) p. 885-907. 
Council. One of these criteria calls for the 'stability of institutions guaranteeing [...] the rule of law', in particular regarding the administration of justice. ${ }^{15}$ Partly under the influence of international soft law, ${ }^{16}$ which is often formulated by judges, the European Commission interpreted this criterion in such a way that neither the executive nor legislative branch, but rather the judiciary must take decisions on its budget and the appointment, promotion and dismissal of judges. ${ }^{17}$ In this way, judicial self-government became the standard in many Eastern and Central European countries. ${ }^{18}$ Although such judicial selfgovernment enhances the institutional independence of the judicial system as a whole, it also has potential drawbacks. Especially in countries whose judicial officials have not been brought up in a culture that values the independence of individual judges, the autonomy of judges can suffer; in a system of judicial selfgovernment, there is no external oversight to counter these judicial officials.

Against this background, the aim of this article is threefold. First, I will provide an analysis of the concept of 'internal judicial independence' in the Court's case law. Although there is a growing body of literature that explores the importance of the concept, ${ }^{19}$ no extensive analysis of the Strasbourg case law on internal judicial

${ }^{15}$ See < www.europarl.europa.eu/enlargement/ec/pdf/cop_en.pdf>, visited 15 January 2019. The transition towards an independent judicial branch in these countries started earlier. See R. Coman, 'Quo Vadis Judicial Reforms? The Quest for Judicial Independence in Central and Eastern Europe', 66(6) Europe-Asia Studies (2004) p. 892; P.C. Magelhães, 'The Politics of Judicial Reform in Eastern Europe', 32(1) Comparative Politics (1999) p. 43; D. Piana, 'The Power Knocks at the Court's Back Door. Two Waves of Postcommunist Judicial Reforms', 42(6) Comparative Political Studies (2009) p. 816.

${ }^{16}$ M. Bobek and D. Kosař, 'Global Solutions, Local Damages: A Critical Study in Judicial Councils in Central and Eastern Europe', 15(7) German Law Journal (2014) p. 1263.

${ }^{17}$ A. Seibert-Fohr, 'Judicial Independence in European Union Accessions: The Emergence of a European Basic Principle', German Yearbook of International Law (2009) p. 423; D. Kochenov, EU Enlargement and the Failure of Conditionality. Pre-accession Conditionality in the Fields of Democracy and the Rule of Law (Kluwer 2009) p. 259 ff.

${ }^{18}$ Bobek and Kosař, supra n. 16, p. 1266. The best-known exception is the Czech Republic. There, the Ministry of Justice Model is applied, which paradoxically enough operates as a form of judicial self-rule. See Kosař, supra n. 13, p. 5 and D. Kosař, 'Politics of Judicial Independence and Judicial Accountability in Czechia: Bargaining in the Shadow of the Law between Court Presidents and the Ministry of Justice', 13(1) EuConst (2017) p. 96.

${ }^{19}$ See e.g. S.B. Burbank, B. Friedman and D. Goldberg, 'Introduction', in S.B. Burbank and B. Friedman (eds.), Judicial Independence at the Crossroads: An Interdisciplinary Approach (Sage Publications 2002) p. 30; C. Guarnieri, 'Judicial Independence in Europe: Threat or Resource for Democracy', 49(3) Representation (2013) p. 347; R.D. Lefever, 'The Integration of Judicial Independence and Judicial Administration. The Role of Collegiality in Court Governance', 24(2) The Court Manager (2009) p. 5; D. Kosař, Perils of Judicial Self-Government in Transitional Societies (Cambridge University Press 2017) p. 408-409; Kosař, supra n. 18, p. 114-122; M. Popova, Politicized Justice in Emerging Democracies. A Study of Courts in Russia and Ukraine (Cambridge University Press 2012) p. 134-139; P.H. Russel, 'Towards a General Theory of Judicial 
independence is available. Second, I will show that, although the Court has only found violations of internal judicial independence in cases against former Communist countries, the concept of internal judicial independence is also relevant for the established democracies party to the Council of Europe. To that end, I will present a case study in which I apply the Strasbourg case law on internal judicial independence to the Netherlands. Third, I will offer a critique of the Court's case law.

I will argue that the Strasbourg case law on internal judicial independence amounts to a fundamental change in what Kosař and Lixinski call the 'judicial design agenda' of the Strasbourg Court. ${ }^{20}$ Until now this fundamental change has not been reflected by any adjustment of the interpretation of the two founding concepts in the case law on Article 6 of the Convention: independence and impartiality. For the conceptual clarity of the Strasbourg case law and, therefore, for its effectiveness and persuasiveness, however, I think that such an adjustment is needed. To that end, I will propose several adjustments to the Court's case law.

I will proceed as follows. After remarking on the methodology applied, I will discuss and systematise the relevant case law. Next, I will demonstrate the relevance of the concept of internal judicial independence for established democracies, offer a critique of the Court's case law, and propose a number of improvements. Finally, I will draw a brief conclusion.

\section{Methodology}

According to the Strasbourg Court, the concept of internal judicial independence is part of Article 6.1 of the Convention. The relevant provision reads as follows:

'... everyone is entitled to a fair and public hearing ... by an independent and impartial tribunal established by law'.

How the Court fits this new aspect of judicial independence into its case law on Article 6 is clearly shown in Parlov-Tkalčić v Croatia (2009). First, it summarises its case law on the requirement of an independent tribunal:

'The Court ... reiterates that in order to establish whether a tribunal can be considered "independent" for the purposes of Article $6 \$ 1$, regard must be had, inter alia, to the manner of appointment of its members and their term of office, the

Independence', in P.H. Russel and D.M. O'Brien, Judicial Independence in the Age of Democracy. Critical Perspectives from Around the World (University Press of Virginia 2001) p. 1.

${ }^{20}$ D. Kosař and L. Lixinski, 'Domestic Judicial Design by International Human Rights Courts', 109(4) The American Journal of International Law (2015) p. 714. 
existence of safeguards against outside pressures and the question whether it presents an appearance of independence'. ${ }^{21}$

Next, the Court argues that this provision requires more than just freedom from outside pressure:

'However, judicial independence demands that individual judges be free not only from undue influences outside the judiciary, but also from within. This internal judicial independence requires that they be free from directives or pressures from the fellow judges or those who have administrative responsibilities in the court such as the president of the court or the president of a division in the court. The absence of sufficient safeguards securing the independence of judges within the judiciary and, in particular, vis-à-vis their judicial superiors, may lead the Court to conclude that an applicant's doubts as to the (independence and) impartiality of a court may be said to have been objectively justified..$^{22}$

When determining the consequences of a violation of internal judicial independence, it should be noted that only in very few cases has the Court focused on the requirement that tribunals be 'independent ${ }^{23}$ In most cases, such as in Parlov-Tkalčic v Croatia, the Court has emphasised the requirement that tribunals be 'impartial'. In other cases, a violation of internal judicial independence has led the Court to the conclusion that there was no 'tribunal established by law' - another requirement of Article 6.1. ${ }^{24}$ This judgment usually follows when an official of the judiciary has taken a case away from a judge and the Court finds that by doing so it had created the impression that an attempt had been made to influence the outcome of the case. ${ }^{25}$ Because a violation of internal judicial independence can thus lead to a violation of the various requirements laid down in Article 6, the case law I will discuss has not been selected on the basis of which requirement the Court deemed had been breached, but rather on the substance of the Court's considerations that underlies those judgments.

The case law that I will discuss here was selected by consulting Hudoc, the case law database of the Strasbourg Court. ${ }^{26}$ I did not confine my search to 'judgments' but also included 'decisions' of the Court dealing with Article 6.1. As noted above, the number of cases in which the Court has dealt with internal judicial

${ }^{21}$ ECtHR 22 December 2009, Case No. 24810/06, Parlov-Tkalčić v Croatia, para. 86 (internal references omitted).

${ }^{22}$ ibid.

${ }^{23}$ Khrykin v Russia; ECtHR 19 April 2011, Case No. 33 188/08, Baturlova v Russia; ECtHR 3 May 2011, Case No. 30024/02, Sutyagin v Russia.

${ }^{24}$ E.g. ECtHR 12 January 2016, Case No. 57774/13, Miracle Europe Kft v Hungary, para. 67.

${ }^{25}$ ibid., para. 58.

${ }^{26}$ See $<$ hudoc.echr.coe.int $>$. 
independence is quite limited. ${ }^{27}$ Only 15 judgments and 3 relevant decisions were found in the period between 2000 and $2018 .^{28}$

\section{Systematic analysis of THE CASE LAW}

Although the reasoning of the Strasbourg Court in its case law usually focusses strictly on the individual case in question, meaning that judgments in which the Court explains the role that it plays in the body of case law as a whole or in which it formulates general rules are rare, ${ }^{29}$ this, I think, does not prevent us from summarising its case law on internal judicial independence in a single legal rule. This rule runs as follows:

Internal judicial independence is breached if

(1) a colleague

(2) who can exert pressure on the judge

(3) tries to influence the judge's decision in a concrete case.

I will discuss the various elements of this rule in the light of the Court's case law.

\section{A Colleague ...}

Internal judicial independence, as defined by the Court, bears on the relationship between judges or between a judge and other judicial officials. In Parlov-Tkalčić v Croatia the Court states:

${ }^{27}$ This search extended through 15 November 2018. Subsequent cases are not considered here.

${ }^{28}$ ECtHR 10 October 2000, Case No. 42095/98, Daktaras v Lithuania; ECtHR 6 September 2005, Case No. 65518/01, Salov v Ukraine; ECtHR 3 May 2007, Case No. 7577/02, Bochan v Ukraine; ECtHR 26 July 2007, Case No. 29294/02, Hirschhorn v Romania; ECtHR 9 October 2008, Case No. 62936/00, Moiseyev v Russia; ECtHR [DA] 14 May 2009, Case No. 2329/05, Zaytsev v Russia; ECtHR [DA] 17 November 2009, Case No. 39279/05, Iwańńczuk v Poland; Parlov-Tkalčić v Croatia, supra n. 21; ECtHR 15 July 2010, Case No. 16695/04, Gazeta UkraineTsentr v Ukraine; ECtHR 5 October 2010, Case No. 19334/03, DMD Group, a.s. v Slovakia; ECtHR 3 February 2011, Case No. 8921/05, Igor Kabanov v Russia; ECtHR 19 April 2011, Case No. 33186/08, Khrykin v Russia; supra n. 23; Baturlova v Russia, supra n. 23; ECtHR 3 May 2011, Case No. 30024/02, Sutyagin v Russia; ECtHR 6 October 2011, Case No. 23465/03, Agrokompleks v Ukraine; ECtHR [DA] 7 July 2015, Case No. 24876/07, Lorenzetti v Italy; Miracle Europe Kft v Hungary, supra n. 24; Ramos Nunes de Carvalho e Sá v Portugal, supra n. 11.

${ }^{29}$ This does not take away from the fact that fewer judgments by the Court are case-bound (J.H. Gerards, General Principles of the European Convention on Human Rights (Cambridge University Press 2019, forthcoming) ch. 2). An example of this (related to internal judicial independence) is Parlov-Tkalčić v Croatia, supra n. 21, para. 86. 
'[I]nternal judicial independence requires that [individual judges, JS] be free from directives or pressures from the fellow judges or those who have administrative responsibilities in the court such as the president of the court or the president of a division in the court'. ${ }^{30}$

Internal judicial independence thus regulates the relationship between judges, i.e. between a member of a judicial panel and its chairman, but it also pertains to the relationship between a judge and 'his' court executives. ${ }^{31}$ It also applies to court executives who are themselves not involved in judging, as ParlovTkalcic also shows. In that case the Court held that the applicant's doubts that the judges in his case were influenced by their court president were objectively justified, although court presidents under Croatian law only perform 'administrative (managerial and organizational) functions which are strictly separated from the judicial function, that is, from adjudication of individual cases. ${ }^{32}$

From the Court's definition, it follows that when pressure is exerted on a judge by anyone other than a judicial official, the concept of internal judicial independence does not apply. Usually, this distinction is easy to make. Sometimes, however, it is not. I will discuss two examples. First, does internal judicial independence apply when the pressure on a judge originates from a body consisting of judicial officials and other (non-judicial) officials? Denisov v Ukraine is an example of such a case. ${ }^{33}$ Denisov, the presiding judge of the Kyiv Administrative Court of Appeal, was dismissed from the office of president by the High Council of Justice, whose membership consists largely of non-judicial staff, including the Prosecutor-General and other representatives of the prosecutorial system. ${ }^{34}$ Denisov then unsuccessfully challenged his dismissal before the Higher Administrative Court. Before the Strasbourg Court, Denisov argued that the Ukrainian Administrative Court had not provided him with access to an independent and impartial tribunal because its members were under the disciplinary jurisdiction of the High Council of Justice, whose decision was the subject of the appeal. The Grand Chamber of the Strasbourg Court agreed with the applicant. However, it did not specify whether this violation of Article 6 of the

\footnotetext{
${ }^{30}$ Parlov-Tkalčić v Croatia, supra n. 21, para. 86.

${ }^{31}$ Apart from this, I am not aware of any other cases in which the Strasbourg Court has complained about unjustified influence by a judicial official other than a court executive. Thus, violations of internal judicial independence by fellow judges who have no executive tasks do not occur. This is probably because such fellow judges without executive tasks also lack the powers necessary to exert influence.

${ }^{32}$ Parlov-Tkalčić v Croatia, supra n. 21, para. 88.

${ }^{33}$ ECtHR 25 September 2018, Case No. 76639/11, Denisov v Ukraine, para. 79.

${ }^{34}$ ibid., para. 69.
} 
Convention amounted to a violation of external or internal judicial independence. In my opinion, the concept of internal judicial independence did not apply in this case since the majority of the members of the High Council of Justice were not judicial officials. ${ }^{35}$

Another situation in which it is not immediately clear whether the concept of internal judicial independence applies is when judicial officials, in pressuring a judge, act in line with the wishes of government officials from outside the judiciary and thus act as transmission belts for another branch of government. ${ }^{36}$ In such cases, the Court considers both internal and external independence to be applicable, as in Agrokompleks v Ukraine. Agrokompleks had supplied 375,000 tonnes of crude oil to LyNOS, a company whose majority-owner was the Ukrainian government. However, LyNOS, in turn, delivered only a small part of the agreed-upon oil products to Agrokompleks. A domestic court established that LyNOS had defaulted on its contractual obligations and ordered payment of about $€ 19.5$ million to Agrokompleks. After that judgment had become final, the government started an inquiry into the liabilities of LyNOS to its creditors, upon which it was concluded that the outstanding liability to Agrokompleks was in fact much lower than the court had established. LyNOS relied on that conclusion as a newly-discovered circumstance and applied for a review of the court order by a panel of the court. The court, finding that the government report did not contain new information, upheld its ruling. ${ }^{37}$ The president of the court, however, after receiving numerous letters from various government officials including the Speaker of Parliament, the Prime Minister, and the President of Ukraine urging him to repeal or reconsider the court's decisions, ${ }^{38}$ instructed his two deputies to review that latest ruling. ${ }^{39}$ The court then proceeded to reverse its earlier ruling. ${ }^{40}$ The Strasbourg Court held that the interference of these government officials with the court proceedings constituted a violation of external judicial independence as laid down in Article 6 of the Convention. ${ }^{41}$ However, the Court also ruled that the instruction given by the president of the court to his two deputies asking them to reconsider the earlier judgment was itself in

\footnotetext{
${ }^{35}$ The Court attaches particular importance to this majority-rule in judicial councils. See ECtHR 9 January 2013, Case No. 21722/11, Oleksandr Volkov v Urkaine, paras. 109 and 112.

${ }^{36}$ On the transmission-belt thesis with regard to court presidents, especially in Central and Eastern European countries, see e.g. Kosař, supra n. 13, p. 99-100 and p. 391-398; Popova, supra n. 19, p. 139-145.

${ }^{37}$ Agrokompleks v Ukraine, supra n. 28, para. 69.

${ }^{38}$ ibid., para. 13.

${ }^{39}$ ibid., paras. 70 and 138.

${ }^{40}$ ibid., paras. 71-72.

${ }^{41}$ The Court labelled this intervention 'unacceptable' (ibid., para. 135).
} 
contravention of the Convention as it, too, violated the principle of internal judicial independence. ${ }^{42}$

... who can exert pressure on the judge ...

Not every judicial colleague is equally relevant when investigating a violation of internal judicial independence. Only colleagues capable of exerting pressure on a judge are of importance here. Whether a colleague can apply such pressure is determined by the Strasbourg Court on the basis of the powers that the colleague in question has. ${ }^{43}$

Some powers are not relevant for this purpose. For example, the Court also takes into account that, within courts, the exercise of certain managerial powers and the ensuing pressure - is inevitable:

'It has to be borne in mind that any supervision of the work of judges involves a certain risk to their internal independence and that it is impossible to devise a system that would completely eliminate that risk' ${ }^{44}$

The mere fact that a colleague has executive power over a judge, for example, because he is the president of the court to which the judge is assigned, is therefore insufficient to justify the assumption that he can exert pressure on the judge to such an extent that it could result in a violation of internal judicial independence. ${ }^{45}$

When examining whether a judicial colleague can exert pressure on the judge, the Court looks at whether one of the following two circumstances apply: has the colleague (a) exercised powers with regard to the handling of a case that is or has been assigned to the judge, or (b) does he have the power to change the legal status of the judge?

\footnotetext{
${ }^{42}$ ibid., para. 139.

${ }^{43}$ See, e.g., Lorenzetti v Italy, supra n. 28, para. 52.

${ }^{44}$ ibid., para. 91.

${ }^{45}$ Only in exceptional cases will an investigation into these powers not be conducted. Agrokompleks v Ukraine, supra n. 28, is an example of such an exception. The Court concluded in this case that the influence exerted on the judge had come from his judicial superior, without addressing the latter's powers with respect to the judge (para. 139). The fact that the Court chose not to conduct a detailed investigation was perhaps because a violation of Art. 6 ECHR had already been established on other grounds and because of the barely-concealed manner in which the pressure had been exerted.
} 
Powers exercised with regard to the handling of a case

When examining whether a colleague has used powers with regard to the handling of a case, this usually concerns the power to assign a case to a particular judge or panel of judges or the right to appoint a judge-rapporteur. ${ }^{46}$ Daktaras v Lithuania illustrates both elements.

The applicant had been convicted by a court of first instance as the principal offender in a blackmail charge. ${ }^{47}$ On appeal, that judgment was amended in that the applicant was no longer regarded as the principal offender but only as a secondary party to the crime. However, the penalty remained the same. ${ }^{48}$ Subsequently, the judge who had pronounced judgment at the Court of First Instance asked the President of the Criminal Division of the Supreme Court to lodge a petition with the Supreme Court requesting the repeal of the Court of Appeal's judgment. ${ }^{49}$ The President of the Criminal Division of the Supreme Court granted that request and petitioned the Supreme Court to repeal the judgment of the Court of Appeal as it had erred in applying the law and had wrongly held that the applicant was not the principal offender. The President asked the Supreme Court to uphold the judgment by the Court of First Instance instead. ${ }^{50}$ Subsequently, he appointed a Chamber of three judges of the Criminal Division of the Supreme Court to examine the case, and he appointed a judgerapporteur. ${ }^{51}$ The Chamber of the Supreme Court subsequently overturned the judgment of the Court of Appeal and upheld the judgment of the Court of First Instance. ${ }^{52}$ In Strasbourg, the applicant complained that the Chamber of the Supreme Court that had heard the petition could not be considered an impartial tribunal within the meaning of Article 6 of the Convention because it was the President of the Criminal Division of the Supreme Court who had lodged the petition and that the same President had appointed the members of the Chamber and the judge-rapporteur. ${ }^{53}$

The Lithuanian government argued that the power of the President to lodge petitions with the Supreme Court requesting the repeal of judgments by lower courts is based on the need to prevent judicial error; that the domestic statutes gave

\footnotetext{
${ }^{46}$ See, e.g., Parlov-Tkalčićv Croatia, supra n. 21, paras. 88-90. Prior to this, the Court had always assumed that the treaty did not regulate the assignment of cases, or at least that it was not an element relevant to the 'establishment of the court'. See ECtHR 9 March 1999, Case No. 32813/96, Lindner v Germany.

${ }^{47}$ Daktaras v Lithuania, supra n. 28, para. 17. See also Igor Kabanov v Russia, supra n. 28.

${ }^{48}$ ibid., para. 19.

${ }^{49}$ ibid., para. 21.

${ }^{50}$ ibid., para. 22.

${ }^{51}$ ibid., para. 23.

52 ibid., para. 25.

${ }^{53}$ ibid., para. 28.
} 
the President only organisational functions; that the President did not take part in the examination of the case; and that he had no legal power to influence the Chamber's decision or to otherwise exert inappropriate pressure on the Chamber's judges. The Government moreover presented 11 decisions by the Supreme Court in which petitions by the President of the Supreme Court or its Criminal Division had been rejected by the Supreme Court. ${ }^{54}$

The Court rejected the arguments made by the government and found a violation of Article 6 of the Convention. It held that the applicant's fears about the impartiality of the Chamber were justified. ${ }^{55}$ The fact that the President of the Criminal Division of the Supreme Court had requested confirmation of a decision that was detrimental to the applicant was evidence that the President had taken sides. ${ }^{56}$ Because he had, moreover, appointed the judges of the Chamber and the judge-rapporteur, the impression was created that the judges who had heard the case had been subject to pressure to decide in accordance with the wishes of their President. ${ }^{57}$ The Court stated:

'[W] hen the President of the Criminal Division not only takes up the prosecution case but also, in addition to his organisational and managerial functions, constitutes the court, it cannot be said that, from an objective standpoint, there are sufficient guarantees to exclude any legitimate doubt as to the absence of inappropriate pressure. ${ }^{58}$

${ }^{54}$ ibid., para. 29.

${ }^{55}$ ibid., para. 38.

${ }^{56}$ ibid., para. 35.

${ }^{57}$ Cf. ECtHR 4 March 2015, Case No. 36073/04, Fazl Aslaner v Turkey, in which the General Assembly of the Supreme Administrative Court heard an appeal in a case that a Division of the Court had ruled on earlier. The members of that Division were also members of the General Assembly. One of them, a vice-president of the court, even presided over the General Assembly. The Strasbourg Court ruled that this constituted a violation of Art. 6 of the Convention because it was not 'absolutely necessary' for the three judges to sit on the bench of the General Assembly (para. 40). Moreover, the Court considered that the fact that one of the three judges had presided over the General Assembly as vice-president was an 'additional circumstance incompatible with the appearance of impartiality' (para. 41). One could argue that the latter argument refers to internal judicial independence, since it points out that the presiding judge was not only a member of the division that had ruled on the case earlier but was also a vice-president of the court. Such judicial officials are (by law or by practice) important figures in court administration, and therefore not easily contradicted by other judges. However, since the Strasbourg does not explicitly adopt this line of reasoning in Fazl Aslaner v Turkey or in other similar cases, I have not included it in my set of cases on internal judicial independence.

${ }^{58}$ Daktaras v Lithuania, supra n. 28, para. 36. It continues: 'The fact that the President's intervention was prompted by the first-instance judge only aggravates the situation'. Cf. Igor Kabanov v Russia, supra n. 28, para. 42. 
The fact that, in other cases, a President's petition had not been granted did not change the Court's view: every case must be assessed on its own merits. ${ }^{59}$

The power to remove a case from a judge is a variant of the power to assign a case to a specific judge or judicial panel. Most Strasbourg cases on internal judicial independence deal with this variant. By removing a case from a judge, the impression could arise that the first judge intended to decide the case in a way that would contradict the wishes of the person who assigned the case. ${ }^{60}$ A striking example of this is Moiseyev $\mathrm{v}$ Russia. The applicant had been indicted for treason. At trial, the president of the court replaced all the judges of the chamber hearing the case no less than three times. The Court considered this to be a violation of Article 6 of the Convention because the applicant was justified in the impression that the judges had been replaced because they intended to decide differently from what the president had in mind. ${ }^{61}$

\section{Having the power to change the legal status of the judge}

If a judicial colleague has not exercised any powers with regard to a specific case, as in the examples above, the Court examines whether there are (other) powers he can wield to exert pressure on the judge. At this point, it is important to stress that a violation of internal judicial independence does not require that the colleague has actually exercised his powers or even merely threatened to exercise them. This criterion, therefore, differs substantially from the previous one. The Court stated:

'the question is whether the powers conferred on the court presidents under the [domestic] law were capable of generating latent pressures resulting in judges' subservience to their judicial superiors or, at least, making individual judges reluctant to contradict their president's wishes, that is to say, of having "chilling" effects on the internal independence of judges. ${ }^{62}$

As mentioned, the Court also takes into account that, within courts, the exercise of certain managerial powers - and the resulting pressure - is inevitable. The mere fact that a colleague can exercise these powers over a judge is therefore insufficient to assume that inadmissible pressure in the sense of Article 6 of the Convention

${ }^{59}$ ibid., para. 37. Another example in which the Strasbourg Court finds that a president of a court has tried to influence the outcome of a case by taking a procedural decision, is ECtHR 26 July 2007, Case No. 29294/02, Hirschhorn v Romania, paras. 76-78.

${ }^{60}$ See also ECtHR 5 October 2010, Case No. 19334/03, DMD Group, a.s. v Slovakia, in which a judicial colleague re-assigned the case to himself. The Court held that this re-assignment violated Art. 6 of the Convention.

${ }^{61}$ Moiseyev v Russia, supra n. 28, paras. 181-185. A comparable situation appears in Sutyagin v Russia, supra, n. 28. For an example in which a case was not reassigned within a court but referred to another court, see Miracle Europe Kft v Hungary, supra n. 24.

${ }^{62}$ Parlov-Tkalcić v Croatia, supra n. 21, para. 91. 
has been exerted. ${ }^{63}$ The Court's examination, therefore, focuses on other powers, namely powers that can lead to changes in the legal status of the judge. In practice, the Court focuses on the power to promote judges or to impose disciplinary sanctions on them. It does so because these powers, as the Court states, 'potentially have the most significant impact on the internal independence of judges'. ${ }^{64}$

Gazeta Ukraine-Tsentr v Ukraine illustrates how the Court conducts such an examination. ${ }^{65}$ In a newspaper published by the applicant, the applicant had reported on a press conference in which the president of a local court - who was also a candidate in a mayoral election - had been accused by a journalist of having had put out a contract for the murder of the applicant. The president then sued the journalist for defamation. Another court than that of the president heard the defamation case and ordered the applicant to pay the president compensation. The Court of Appeal confirmed that judgment. In Strasbourg, the applicant argued that neither court could be deemed impartial within the meaning of Article 6 of the Convention. He argued that, although a different court than that of the president had heard his case, the president was also the chairman of the Regional Council of Judges, under whose authority both the Court of First Instance and the Court of Appeal fell, and that the plaintiff was therefore entitled to propose to the Council that disciplinary proceedings be instituted against the judges and that another decision affecting their legal status be taken. The applicant argued that the judges of these courts, therefore, lacked the appearance of impartiality. The Court agreed and ruled that Article 6 of the Convention had been violated. ${ }^{66}$

\section{... tries to influence the judge's decision in a concrete case}

The mere fact that a colleague of the judge has used powers with regard to the handling of a specific case or has (other) powers he can use to exert pressure on the judge does not mean that he has actually tried to influence the judge. For example,

${ }^{63}$ ibid., para. 91.

${ }^{64}$ ibid., paras. 92-93.

${ }^{65}$ See also Khrykin v Russia, supra n. 28, paras. 36-39.

${ }^{66}$ Gazeta Ukraine-Tsentr v Ukraine, supra n. 28, paras. 34-35. The Court furthermore considered it relevant that plaintiff had already asked the Supreme Court, even before the handling of his case had started, to transfer the case to an entirely different court for the same reasons that he presented in Strasbourg. The Supreme Court, in a decision issued by its vice-president, granted this request but regarded the case in first instance as completed, so that the verdict had no consequences for the current proceedings. The Court stated: 'Although this decision by the Deputy President of the Supreme Court did not state clearly the reasons for the transfer, it suggested that the applicant company's fear about a risk of bias of the courts in the Kirovograd region was not without substance. Therefore, in the Court's view, the applicant company's fears that judges of first-instance and appellate courts lacked impartiality can be held to be objectively justified. Moreover, the higher courts, in dealing with the applicant company's appeals, disregarded its submissions to this effect' (para. 34). 
a case can rightly be assigned to a different judge if, for example, the first judge has fallen ill. There is also nothing illegal about a judge being warned that disciplinary measures might be issued against him if, for example, he has neglected the duties of his office. The assertion that a judicial colleague has actually tried to influence the judge must, therefore, be proven in both cases. Providing such evidence is difficult because the intent to influence is rarely openly expressed.

Agrokompleks v Ukraine, discussed above, is an exception to the rule that judicial influencing does not occur out in the open. ${ }^{67}$ In that case, various government officials, including the Speaker of Parliament, the Prime Minister and the President of Ukraine, urged the president of a domestic court to repeal or reconsider a decision of 'his' court. ${ }^{68}$ Eventually, the court president instructed his two deputies to review that ruling, ${ }^{69}$ which the court eventually did. ${ }^{70}$ The Strasbourg Court ruled, inter alia, that the instruction, given by the president of the court to his two deputies, to reconsider an earlier judgment contravened the Convention as it violated the principle of internal judicial independence. ${ }^{71}$

Usually, however, attempts to influence judges are discreet. Proving that a judge has been influenced (or that an attempt thereto has been made) is therefore quite difficult. Hence, the Court has simplified the burden of proof with regard to judicial influencing, basing it on the general rule that Article 6 of the Convention is not only violated when a judge is not independent or impartial but also when there are legitimate doubts about his independence or impartiality. In practice, this requirement of 'objective' independence and impartiality ${ }^{72}$ results in the applicant focusing on establishing doubt about the judge's independence and impartiality; in response, the state will then argue that such doubt cannot be held objectively justified. ${ }^{73}$

${ }^{67}$ See, the text accompanying n. 36.

${ }^{68}$ ibid., para. 13.

${ }^{69}$ ibid., paras. 70 and 138.

${ }^{70}$ ibid., paras. 71-72.

${ }^{71}$ ibid., para. 139.

${ }^{72}$ With regard to impartiality, see, for example, ECtHR 23 April 2015, Case No. 29369/10, Morice v France, para. 73 ('According to the Court's settled case-law, the existence of impartiality for the purposes of Article $6 \$ 1$ must be determined according to a subjective test where regard must be had to the personal conviction and behaviour of a particular judge, that is, whether the judge held any personal prejudice or bias in a given case; and also according to an objective test, that is to say by ascertaining whether the tribunal itself and, among other aspects, its composition, offered sufficient guarantees to exclude any legitimate doubt in respect of its impartiality'). It is less clear that the same distinction would apply for independence, but see, for example, Kleyn et al. $\mathrm{v}$ The Netherlands, supra n. 11, in which the Court considered that it needed to determine whether the Administrative Jurisdiction Division of the Dutch Council of State 'had the requisite "appearance" of independence' (para. 193).

${ }^{73}$ Of course, the following does not alter the fact that applications before the Strasbourg Court are inadmissible if the applicant has not exhausted all domestic remedies against an actual or potential infringement of internal judicial independence: see Zaytsev v Russia, supra n. 28. 
To show how this simplified burden of proof works out for both the applicant and the respondent state, it is again necessary to differentiate between situations in which a judicial colleague (a) has exercised powers with regard to the handling of a case which is (or was) assigned to the judge, and situations (b) in which he has the power to change the legal status of the judge, irrespective of whether he actually uses that power.

For the applicant, the foregoing mitigates the burden of proof. He no longer has to provide a 'smoking gun'. Instead, the focus is on establishing that there could be doubts about the independence and impartiality of the judge who heard the case. To understand what this burden of proof requires, it is important to stress that a violation of Article 6 of the Convention of the Strasbourg Court does not require that the attempted influencing was successful. Under the established case law, it is sufficient that officials from the legislative or executive branch merely try to influence the judge. In such cases, the Court considers that the mere attempt to influence a judge reveals such a lack of respect for the judicial office that there is sufficient reason to doubt that the judge is independent or impartial. ${ }^{74}$ It is fair to assume that the same applies if an official within the judiciary attempts to influence a judge. ${ }^{75}$ In order to explain how this alleviation of the burden of proof works in practice, it is again necessary to differentiate between two situations.

If a judicial colleague has exercised powers with regard to the handling of a specific case such as re-assigning the case or appointing a judge-rapporteur, that mere fact creates doubt about the impartiality and independence of the judge who hears the case. Usually, however, there is additional evidence of judicial influencing or attempts thereto, but such additional evidence is not necessary to establish the required doubt. Moiseyev v Russia, discussed above, shows this. In that case, the president of the court repeatedly replaced the entire judicial panel trying the case; in fact, the case was re-assigned no less than three times. ${ }^{76}$ The Strasbourg Court stated that the fact that the panels had been replaced was enough to raise doubts about the independence and impartiality of the judges who eventually decided the case. ${ }^{77}$

\footnotetext{
${ }^{74}$ Agrokompleks v Ukraine, supra n. 28, para. 134, with reference to ECtHR 25 July 2002, Case No. 48553/99, Sovtransavto Holding v Ukraine, para. 80 ('The Court sees no reason to speculate on what effect such interventions may have had on the course of the proceedings in issue, but finds that in the circumstances of the present case the applicant company's concerns as to the independence and impartiality of the tribunals were not unreasonable. Coming from the executive branch of the State, such interventions nonetheless reveal a lack of respect for the judicial office itself).

${ }^{75}$ If the exerted pressure has in fact had an effect, the Court then usually mentions this. See, e.g., Khrykin v Russia, supra n. 28, para. 37.

${ }^{76}$ Moiseyev v Russia, supra n. 28.

${ }^{77}$ The Court considered in this regard that there were also no procedural guarantees that could undo this appearance. I will discuss the importance of these procedural guarantees below.
} 
If the judicial colleague has not exercised any power with regard to the handling of a specific case but does have the power to change the legal status of the judge, more evidence is needed to establish the necessary doubt that a violation of internal judicial independence has taken place. Additional facts and circumstances are needed, as Khrykin $\mathrm{v}$ Russia shows. ${ }^{78}$ In that case, the applicant had asked the authorities to upgrade his retirement pension retroactively. A judge of the Elektrostal Town Court granted that request. After the judgment became final, the pension fund lodged an application for supervisory review of that judgment with the Moscow Regional Court. That application was never examined. However, the President of the Court wrote a letter to the judge of the firstinstance court, stating that he considered the latter's decision to be incompatible with the case law of the Supreme Court, 'a judicial error' that 'cannot be regarded lawful'. Therefore, the President of Regional Court wrote, the case should be reconsidered on the basis of newly-discovered circumstances. ${ }^{79}$ The pension fund later asked the Court of First Instance to reopen the case. The latter agreed and subsequently rejected the applicant's claim to upgrade his retirement pension. Its findings were identical to the arguments put forward in the letter sent by the President of the Regional Court. ${ }^{80}$ In Strasbourg, the applicant argued that the President's letter had unduly influenced the judgment of the first-instance court. The Court agreed. It reached that conclusion after pointing out a number of additional circumstances. First, the President of the Regional Court never decided on the application for supervisory review, as required by law, but instead wrote a letter to the judge of the Court of First Instance. ${ }^{81}$ Second, unlike the government, the Court found that the President's letter had exerted undue pressure on the judge because of the language used to qualify the judge's decision: a 'judicial error' that 'cannot be regarded lawful'. ${ }^{82}$ Third, the Court noted that the President is empowered to bring disciplinary proceedings against a judge for committing a disciplinary offence. Such proceedings can lead to early termination of office. '[E]rroneous application of the law' can constitute such a disciplinary offence. ${ }^{83}$ Having noted these additional facts and circumstances, the Court concluded that the applicant's fear that the court of first instance was not independent was justified. $^{84}$

${ }^{78}$ See also the identical Baturlova v Russia, supra n. 23. Cf. Ramos Nunes de Carvalho e Sá v Portugal, supra n. 11, paras. 155 and 163, in which the Court held that such additional facts and circumstances were absent, so there was - at that point - no violation of Art. 6 of the Convention.

${ }^{79}$ Khrykin v Russia, supra n. 28, para. 8.

${ }^{80}$ ibid., paras. 9-11.

${ }^{81}$ ibid., para. 32.

${ }^{82}$ ibid., para. 35.

${ }^{83}$ ibid., para. 36.

${ }^{84}$ ibid., paras. 38-39. 
If the applicant successfully raises doubts about the independence and impartiality of the judge in question, the respondent state will try to establish that those doubts are not legitimate, that is, that they cannot be held objectively justified. As a rule of thumb, the Strasbourg Court considers this to be the case if domestic law provides sufficient procedural guarantees to prevent judicial influencing.

In the Court's case law, such safeguards are particularly important when a case is assigned to anyone other than the usual judge or when a case has been reassigned. For example, in Miracle Europe Kft $\mathrm{v}$ Hungary the Court emphasised the importance of regulating, by law, the way cases are distributed among the judges of a court and warned against the lack of clear and transparent legal criteria for case distribution:

'that situation puts at risk the appearance of impartiality, by allowing speculation about the influence of political or other forces on the assignee court and the judge in charge, even where the assignment of the case to the specific judge in itself follows transparent criteria'. ${ }^{85}$

In Miracle Europe Kftv Hungary, such a legal framework was lacking. ${ }^{86}$ As a result, the judge who distributed cases had far-reaching discretionary power. The Strasbourg Court considered, therefore, that:

'the allocation or reassignment of cases could be misused as a means of putting pressure on judges by for instance overburdening them with cases or by assigning them only low-profile ones. It is also possible to direct politically sensitive cases to certain judges and to avoid allocating them to others. ${ }^{87}$

The Court concluded that because of the absence of procedural guarantees - such as legislation that significantly restricts the way cases are distributed - the

\footnotetext{
${ }^{85}$ Miracle Europe Kft v Hungary, supra n. 24, para. 58.

${ }^{86}$ For a case in which an adequate legal framework for the distribution of cases among judges was available, see Iwańczuk v Poland, supra $\mathrm{n}$. 28. The Court there emphasised that domestic law regulated the distribution of cases and that although it also provided for exceptions, it also required that the reasons justifying such exceptions be expressly stated. Moreover, the Strasbourg Court attached importance to the fact that the applicant's allegation - that his case had been improperly assigned - had been carefully examined by the Supreme Court and found 'entirely ill-founded'.

${ }^{87}$ Miracle Europe Kft v Hungary, supra n. 24, para. 58. In previous cases, the Court was less stringent, only requiring, for example, that the reassignment had been properly motivated (Bochan $\mathrm{v}$ Ukraine, supra n. 28, para. 72). It has also on occasion considered whether legal remedies were available against a reassignment decision (Moiseyev v Russia, supra n. 28, para. 182; Sutyagin v Russia, supra n. 28, para. 192).
} 
applicant's fears that his case was not heard by 'a tribunal established by law', as Article 6 of the Convention requires, were objectively justified. ${ }^{88}$

Procedural guarantees are also important when a judicial official exerts pressure on a judge by using or referring to his power to change the legal status of the judge. Parlov-Tkalcicí Croatia shows this. ${ }^{89}$ After the applicant had suffered a road traffic accident, the Zlatar Municipal Court ordered the insurance company to pay compensation for the resulting damage. Afterwards, the Municipal Court modified its decision; the interest it had calculated was too high. At that point, however, the insurance company had already paid out the initial judgment, and the applicant refused to pay back the amount in excess. The President of the Municipal Court - after having received a letter from the insurance company filed a criminal complaint against the applicant. He stated that the applicant had refused to return the unlawfully obtained amount, that the insurance company had already instituted civil proceedings against the applicant, and that the applicant's refusal to return the amount 'contains elements of criminal liability'. ${ }^{90}$

As mentioned above, the insurance company had already instituted civil proceedings against the applicant to recover the allegedly wrong amount. The Zlatar Municipal Court - the court of the president who had filed the criminal complaint against the applicant - ruled against the applicant. The applicant appealed to the Zlatar County Court. At the same time, she asked for a transfer of jurisdiction from both the Zlatar Municipal Court and the Zlatar County Court, because both courts, in her view, could not be expected to be impartial in the examination of her appeal, given that the President of the Municipal Court, who had filed a criminal complaint against her, had in the meantime become the President of the County Court. ${ }^{91}$ The Supreme Court dismissed the applicant's request for a transfer of jurisdiction. ${ }^{92}$ The County Court then upheld the judgment of the Municipal Court. ${ }^{93}$ In Strasbourg, the question was whether the judges of either court at which the applicant's case had been heard in civil proceedings were sufficiently independent of the aforementioned president. ${ }^{94}$

The Court noted first that, under Croatian law, the president, rather than performing any judicial functions, only has administrative tasks. The president, therefore, could not 'take advantage of his hierarchical position to give the rapporteur or other members of the panel instructions as to how to decide on the

\footnotetext{
${ }^{88}$ Miracle Europe Kft v Hungary, supra n. 24, para. 67. See also Igor Kabanov v Russia, supra n. 28, paras. 40-44.

${ }^{89}$ See also Salov v Ukraine, supra n. 28, para. 83.

${ }^{90}$ Parlov-Tkalčić v Croatia, supra n. 21, para. 9.

${ }^{91}$ ibid., para. 17.

${ }^{92}$ ibid., para. 19.

${ }^{93}$ ibid., para. 20.

${ }^{94}$ ibid., para. 87.
} 
applicant's appeal, and there is nothing to indicate that he did so in her case'. ${ }^{95} \mathrm{He}$ was, however, charged with the assignment of cases to judges, but - as the Court noted - Croatian law 'contained rules governing the distribution of cases to judges within courts, which means that cases were not distributed by the court presidents at their own discretion'. The Court, therefore, concluded that Croatian law 'provided for adequate safeguards against arbitrary exercise of court presidents' duty to (re)assign cases to judges..$^{6}$ Next, the Court examined 'whether there were any other elements in the (hierarchical) relationship between judges who decided the applicant's appeal and the president of the Zlatar County Court, which were capable of curbing their internal independence'. ${ }^{97}$

The Court next found that court presidents, inter alia, play a role in the appraisal of judges and have the power to initiate disciplinary proceedings against judges and to temporarily suspend judges. 'However', the Court continued, 'in neither of these areas the court presidents had exclusive powers or unfettered discretion'. For example, a judge who receives a negative appraisal can appeal against it to the president of a higher court; while a court president can institute disciplinary proceedings against a judge, the power to impose a disciplinary sanction lies exclusively with the National Judicial Council; and, finally, the power to temporally suspend a judge can only be exercised when a judge is being held in detention. ${ }^{98}$ The Court concluded:

'For these reasons, the Court considers that Croatian law at the material time had adequate mechanisms to prevent improper interferences coming from within the judiciary, and that the powers vested in the court presidents could not have reasonably been viewed as running counter to, or having "chilling" effects on, the internal independence of judges. ... Therefore, the Court considers that the applicant's fears as regards the lack of impartiality of the Zlatar County Court were not objectively justified'. ${ }^{99}$

Article 6 of the Convention had therefore not been violated. ${ }^{100}$

The Strasbourg Court has thus developed some clear rules with regard to the concept of internal judicial independence. What is striking, however, is that the Court

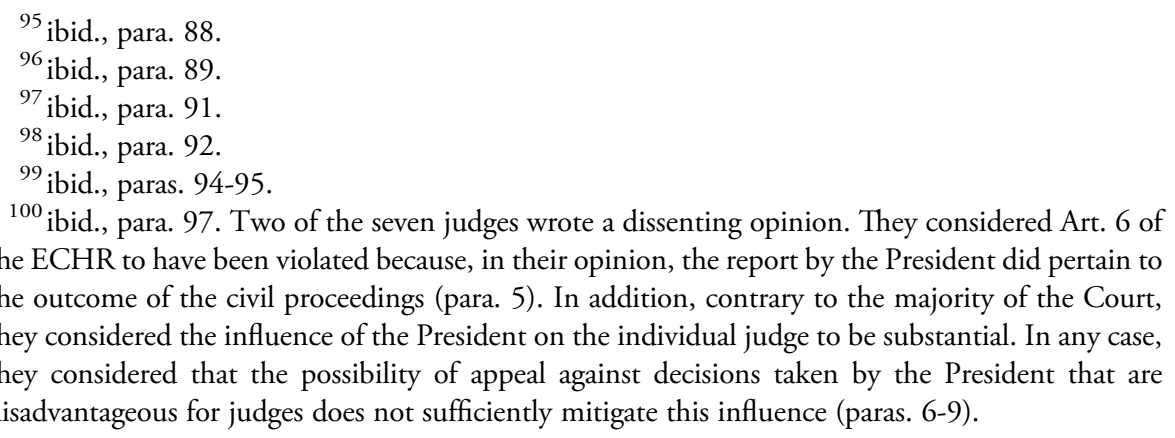


judgments discussed above were issued against only a limited number of postcommunist member states of the Council of Europe. This raises the question whether the concept of internal judicial independence is only relevant for those member states, other whether it has also consequences for the established democracies of the Council of Europe. I will address this question in the next paragraph.

\section{INTERNAL JUDICIAL INDEPENDENCE IN ESTABLISHED DEMOCRACIES: THE NetherLANDS AS A CASE STUDY}

The fact that judgments of the Strasbourg Court in which it has held that internal judicial independence had been violated have been handed down against a limited number of post-Communist states is, in my opinion, due to two circumstances. First, due to their Communist past, these countries lack a long-standing, deeply ingrained culture in which the independence of the individual judge is considered important. Second, many former Communist countries opted for a model of judicial self-government after the fall of the Berlin Wall. In such a model, the independence of the individual judge may suffer, since there is no external control over those who supervise judges. This risk is enhanced if the judicial supervisor has not been exposed to a culture in which the independence of individual judges is considered important; this is exactly the case in the former Communist countries.

The fact that up until now violations of internal judicial independence have only been issued against former Communist countries could easily lead to the conclusion that the case law on internal judicial independence is only applicable to those new democracies that have a model of judicial self-government and that do not have a long-standing judicial culture which acknowledges the importance of the independence of individual judges. But such a conclusion is, in my opinion, unjustified. The mere fact that no cases exist in which the Strasbourg Court has condemned an established democracy for a violation of internal judicial independence does not mean that the internal-independence model in those countries is necessarily in line with the Convention. In that respect, it is important to realise that the Strasbourg tenet of internal judicial independence is intended to protect citizens rather than judges: citizens are entitled to an independent and impartial trial. The fact that no citizens of established democracies have complained to the Strasbourg Court about violations of internal judicial independence is probably because of the relatively great level of trust they place in judges and the judicial organisation; fears that 'their' judge has been put under pressure will not quickly arise. ${ }^{101}$

${ }^{101}$ The EU Justice Scoreboard 2018 provides the necessary information in this regard for EU countries (see <ec.europa.eu/info/policies/justice-and-fundamental-rights/effective-justice/eujustice-scoreboard_en $>$ ). 
To support the proposition that the Court's case law is also relevant for the established democracies of the Council of Europe, I examine whether the court system of the Netherlands - an established democracy in which judicial selfgovernment is rather limited and the importance of judicial autonomy is deeply ingrained in the legal culture - has potentially problematic profiles in the light of the Court's principles on internal judicial independence. ${ }^{102}$

In this examination, I limit myself to the relationship between Dutch judges in courts of first instance and appellate courts on the one hand, and the executive officials of those courts on the other. ${ }^{103}$ As such, I do not consider the situation here of certain administrative law tribunals and the Supreme Court (the court of cassation), since the internal organisation of those bodies differs significantly from the organisation of courts of first instance and appellate courts.

Before 2002, judges essentially ruled over Dutch courts. The so-called general assembly of a court (its 'gerechtsvergadering), consisting of all the judges of a particular court, was its highest executive body. It possessed, for example, the power to institute court chambers, distribute cases, and recommend persons to the Crown for judicial appointment. From the 1980s onward, however, a practice emerged whereby the general assembly delegated its powers to an executive board headed by the court president. In 2002, the law on the Dutch court administration changed significantly. First, the executive boards were given a basis in legislation. Nowadays, the Dutch courts of first instance and appellate courts each have a board consisting of three persons of whom at least two are judges. ${ }^{104}$ One of the two judges acts as the board's chairman and is referred to as its president. ${ }^{105}$ The Government appoints ${ }^{106}$ and dismisses court board

\footnotetext{
${ }^{102}$ For a description of the Dutch judicial organisation in English, see P.P.T. Bovend'Eert, 'Judicial Independence and Separation of Powers: A Case Study in Modern Court Management', 22(2) European Public Law (2016) p. 333; Ph.M. Langbroek, 'Organization Development of the Dutch Judiciary, between Accountability and Judicial Independence', International Journal for Court Administration (April 2010) p. 1; R. de Lange, 'Judicial Independence in The Netherlands', in A. Seibert-Fohr (eds.), Judicial Independence in Transition (Springer 2012) p. 231.

${ }^{103}$ In actual practice, the sectoral, departmental, and team chairmen are likewise important, since they can often exercise the powers of the judicial board by virtue of a mandate on the basis of the management regulations of the court involved. See, for example, Art. 4, subclause 4, of the Management Regulations of the Gelderland Court (Staatscourant [Government Gazette] 2013, no. 9212). In fact, the team chairman does not always have to be (and in some cases is not) a judge (Kamerstukken I [Parliamentary Papers I] 2011/12, 32 891, E, p. 5).

${ }^{104}$ Art. 15(1) and 15(2) Wet op de Rechterlijke Organisatie [Judiciary (Organisation) Act].

${ }^{105}$ Art. 15(3) Wet op de Rechterlijke Organisatie [Judiciary (Organisation) Act].

${ }^{106}$ Art. 15(4) Wet op de Rechterlijke Organisatie [udiciary (Organisation) Act].
} 
members. ${ }^{107}$ Each court board is responsible for the organisation and management of the respective court. Second, a Council for the Judiciary was introduced. Its members, of whom at least half must be judges, ${ }^{108}$ are also appointed ${ }^{109}$ and dismissed ${ }^{110}$ by the Government. The Council operates as a buffer between the Government and the courts. It plays an important role in court financing: it draws up (non-binding) budget proposals and apportions the budget allocated by Parliament and the Government. It moreover provides support to and supervises the court boards. According to the Judiciary (Organisation) Act, the court boards and the Council for the Judiciary may not, in exercising their powers, involve themselves in the handling and decisionmaking process of a concrete case or case categories. ${ }^{111}$

Upon examination of whether the Dutch court system has potentially problematic profiles in the light of the light of the Court's principles on internal judicial independence, three powers wielded by the members of Dutch court boards turn out to be particularly relevant: the power to assign (or re-assign) cases to judges, the power to impose disciplinary penalties or to take the initiative thereto, and the power to promote judges. As regards each of these powers, I discuss whether Dutch law has potentially problematic profiles. ${ }^{112}$ I then present a brief conclusion.

${ }^{107}$ Art. 16 Wet op de Rechterlijke Organisatie [Judiciary (Organisation) Act]. The Council for the Judiciary prepares a non-binding recommendation for their appointment (Art. 15(5) Wet op de Rechterlijke Organisatie [Judiciary (Organization) Act]).

${ }^{108}$ Art. 84(4) Wet op de Rechterlijke Organisatie [udiciary (Organisation) Act].

${ }^{109}$ Art. 84(3) Wet op de Rechterlijke Organisatie [udiciary (Organisation) Act].

${ }^{110}$ Art. 86 Wet op de Rechterlijke Organisatie [Judiciary (Organisation) Act].

${ }^{111}$ Art. 23.2, 24.2 and 96 Wet op de Rechterlijke Organisatie [Judiciary (Organisation) Act]. See P. P.T. Bovend'Eert (with the cooperation of C.A.J.M. Kortmann), Rechterlijke organisatie, rechters en rechtspraak [Judicial Organisation, Judges and the Administration of Justice] (Kluwer 2013) p. 103104; P.M. van den Eijnden, Onafhankelijkheid van de rechter in constitutioneel perspectief [Judicial Independence in a Constitutional Law Perspective] (Kluwer 2011) p. 243-255. These prohibitions are thus tied to the (specific) powers of court administrations and the Council for the Judiciary. The legislature explicitly stated that it was not the intention to recognise or establish internal judicial independence, in general (Kamerstukken II [Parliamentary Papers II] 1999/00, 27 182, no. 3, p. 68 and 83-84).

${ }^{112}$ In the Netherlands, there is debate on whether the Council for the Judiciary and the judicial boards, by exercising their financial powers, might not have excessive influence on the way justice is administered. For example, financial incentives are used to ensure that cases are handled efficiently, making it less worthwhile to handle cases by a three judge panel instead of by a single judge or to hear many witnesses. I shall leave that discussion up to others. See, on this subject, Bovend'Eert, supra n. 102. 


\section{Case assignment}

The power to assign cases lies with the court board, ${ }^{113}$ which establishes rules of procedure for that purpose. ${ }^{114}$ In practice, however, those rules are not hard and fast, and the officials who assign cases (or who are mandated to do so) have great discretionary power. The Dutch practice of case assignment is thus far from transparent. This can lead to judges being challenged, as happened recently during the criminal proceedings against Geert Wilders, a member of the Lower House for the PVV, for causing insult and stirring up hatred. The judges hearing the case had been selected based on the criterion that they were not and had never been members of a political party. That raised the question of whether this could be considered a relevant criterion and, if so, what this meant for judges who were members of a political party. ${ }^{115}$

This discretionary power in the assignment of cases puts the Netherlands in risky territory, as has been noted on various occasions, ${ }^{116}$ especially when no explanation can be given for the choice of criteria, objective or otherwise, used to assign a given case to a particular judge. This legal gap was meant to be bridged by a Case Assignment Code, which a taskforce started work on in 2012. Three years later, however, it was decided to incorporate the aim of improving case assignment into a broader computerisation scheme. ${ }^{117}$ The Minister of Justice expressed the expectation that a 'scheduling and planning tool' would be 'partially operating in several districts ${ }^{\text {'11 }}$ by mid-2017. However, at the time of writing this paper, no such tool is operational.

Court boards are, in addition, free to assign judges of the court to different teams within the same court; a judge could, for example, be assigned to no longer handle criminal cases but only private law cases. As a result, this power functions as a variant of the power to assign cases to a specific judge. For the judge in question, such a reassignment could also prove unwelcome: the judge might, for example, have limited knowledge of private law, or derive greater fulfilment from the adjudication of criminal cases. The threat of reassignment by a court board can thus be an effective way to force an obstreperous judge to back down. Research

${ }^{113}$ Art. 41 Wet rechtspositie rechterlijke ambtenaren [Judicial Officers (Legal Status) Act].

${ }^{114}$ Art. 20.1 Wet op de Rechterlijke Organisatie [Judiciary (Organisation) Act].

${ }^{115} \mathrm{See}$, on this subject, R.J.B. Schutgens, 'Dit is de rechter die de wet u toewijst', RM Themis (2016) p. 113-114.

${ }^{116}$ M.L. van Emmerik et al., Systeemwaarborgen voor de kernwaarden van de rechtspraak (Research Memoranda 2014/2) (Raad voor de Rechtspraak 2014) p. 95-103; R. Baas, 'Hoe een zaak bij de rechter komt', in R. Baas et al. (eds.), Rechtspleging en rechtsbescherming (Kluwer 2015); M.L. Emmerik and Y. Schuurmans, 'Meer transparantie bij rechterlijke zaakstoedeling dringend gewenst', 12 NJB (2016) p. 795.

${ }^{117}$ The programme is referred to as KEI, which stands for Kwaliteit en Innovatie Rechtspraak [Quality and Innovation of the Judiciary].

${ }^{118}$ Aanhangsel Handelingen II [Appendix to Parliamentary Papers II] 2015/16, 2379, p. 2. 
among court presidents shows, by the way, that the majority would opt to impose the sanction of transfer if a judge regularly ignored a national sentencing criterion for a specific offence. ${ }^{119}$ In this respect, the Dutch legal system seems to have potentially problematic profiles in the light of the Court's principles on internal judicial independence.

\section{The power to impose disciplinary penalties}

The threat that the power to impose disciplinary penalties will be used can be a source of pressure on judges. Under current Dutch law, only two types of disciplinary penalties can be imposed: ${ }^{120}$ a written warning or a dismissal. A written warning can only be imposed by a board member of the court in which the judge is in function, i.e. its president. ${ }^{121}$ Disciplinary dismissal of a judge can only be ordered by the Supreme Court, and must be based on a requisition of the Court's - independent - procurator general. ${ }^{122}$ This penalty can therefore not be imposed or requested by courts of first instance or appellate courts, which is the reason I do not address that particular subject here.

Should the impression arise that a judge might decide in a particular way simply to avoid the possibility of a disciplinary warning, procedural guarantees can help prevent that impression from becoming reality. Examples of such guarantees are limitations on the discretion of the penalising authority and the possibility to appeal against sanctions. In the Netherlands, these procedural guarantees appear to be sufficiently available. Although the grounds for imposing such sanctions are ample, ${ }^{123}$ the Dutch legal system recognises no grounds for imposing disciplinary penalties on judges due to the content of a verdict, ${ }^{124}$ as is the case in, for example,

${ }^{119}$ D. Allewijn and A.F.M. Brenninkmeijer, 'De aanspreekbaarheid van de rechter', Trema (2002) p. 266.

${ }^{120}$ An Act has been passed but not yet entered into force that will broaden the range of disciplinary penalties. See Staatsblad [Bulletin of Acts and Decrees] 2018, 298. The Act will introduce the possibility to withhold up to half a month's salary and to suspend a judge from office for the duration of a maximum of three months. Only the Supreme Court will be able to impose these two new disciplinary penalties on judges. By entering into force, the new Act will not in fact change the substance of this paragraph.

${ }^{121}$ Art. 46d(1)(a) Wet rechtspositie rechterlijke ambtenaren [Judicial Officers (Legal Status) Act]. See also Art. 116(4) Grondwet [Constitution].

${ }^{122}$ Art. 117(3) of the Dutch Constitution in combination with Art. 46d.2 and 46o ff of Wet rechtspositie rechterlijke ambtenaren [Judicial Officers (Legal Status) Act].

${ }^{123}$ Possibly too broad in specific cases, according to the Strasbourg Court. See my case note to Volkov v Ukraine, supra n. 35, in EHRC 2013, p. 80.

${ }^{124}$ Supreme Court 15 December 2009, ECLI:NL:HR:2009:BK6646, para. 3.7. Dismissal for incompetence is, however, conceivable if the judge 'consistently applies old law because he 
Russia. ${ }^{125}$ As a result, the power of the president of a court to impose disciplinary warnings cannot readily be wielded to force a judge to issue a specific verdict. In addition, appeals against disciplinary warnings imposed by court presidents can be lodged with the Central Appeals Tribunal, an independent judicial authority. ${ }^{126}$ Hence, as far as this point is concerned, the Dutch legal system seems to provide sufficient guarantees in the light of the Court's principles on internal judicial independence.

\section{The power to promote judges}

Lastly, the power to promote judges, for example to senior judge positions, can be a source of pressure. In the Netherlands, recommendations to promote judges are made by the court board. ${ }^{127}$ Following the advice of the Council for the Judiciary, the Minister of Justice decides whether to recommend the candidate to the King for appointment to the intended function. ${ }^{128}$ Promotion is thus dependant on an initiative to that effect taken by the court board, which is then theoretically in a position to exert pressure on any judge eager for such a promotion. In addition, the court board - convening without its non-judicial member ${ }^{129}$ - conducts judicial performance reviews, ${ }^{130}$ although that authority is generally exercised by someone else, for example, the team chairman. Although performance reviews must be seen as procedurally separate from promotion recommendations, it is not unreasonable to assume that the outcome of those reviews will be considered when deciding whether a judge is to be recommended for promotion. Although the explanatory memorandum to the legal provision that instructs the court board to conduct performance reviews states that the board may - in accordance with the law ${ }^{131}$ - not involve itself 'in the procedural handling of, the substantive evaluation and the decision in a concrete case or in categories of cases', ${ }^{132}$ Strasbourg case law shows that such an exception does not guarantee that the regulation is in line with the Convention. ${ }^{133}$ What does help, however, is to limit

consistently fails to keep up his professional expertise' ('P-G Hoge Raad: ontslag rechter na onjuiste beslissing niet mogelijk', NJB (2009) p. 2791-2793).

${ }^{125}$ See, e.g., Khrykin v Russia, supra n. 28, para. 60.

${ }^{126}$ Art. 3(a), Bevoegdheidsregeling bestuursrechtspraak $[$ Rules on jurisdiction governing administrative decisions].

${ }^{127}$ Art. 5c(1) Wet rechtspositie rechterlijke ambtenaren [Judicial Officers (Legal Status) Act].

${ }^{128}$ Art. 5c(4) and 5c(5) Wet rechtspositie rechterlijke ambtenaren [Judicial Officers (Legal Status) Act].

${ }^{129}$ Art. 37b(4) Besluit rechtspositie rechterlijke ambtenaren [Judicial Officers (Legal Status) Decree].

${ }^{130}$ Art. 37b Besluit rechtspositie rechterlijke ambtenaren [Judicial Officers (Legal Status) Decree].

${ }^{131}$ Art. 23(2) Wet op de rechterlijke organisatie [Judiciary (Organisation) Act].

${ }^{132}$ Staatsblad [Bulletin of Acts and Decrees] 2014, 50, p. 4.

${ }^{133}$ Cf. Daktaras v Lithuania, supra n. 28, para. 26, sub B (the Court assumes violation of the internal judicial independence since the chairman of the criminal division of the Supreme Court had 
the discretion of the office that conducts the performance review, for example by establishing objective criteria for proper functioning and possible promotion. ${ }^{134}$ However, the Dutch judiciary has not established any such criteria. In that respect, therefore, the Dutch law is potentially problematic in the light of the Court's principles on internal judicial independence.

\section{Conclusion}

Although the case-oriented approach of the Strasbourg Court does not always make it easy to assess - strictly on the basis of the applicable rules of law and thus in the absence of a concrete dispute - whether the national law of a member state meets the requirements of the Convention, the above makes clear, in my opinion, that the law on the Dutch court system has potentially problematic profiles in the light of the Court's principles on internal judicial independence, especially with regard to case assignment and the power to promote judges. The fact that the two riskenhancing circumstances for violation of internal judicial independence do not occur in the Netherlands - namely, a culture in which the importance of judicial autonomy is not ingrained, and the existence of solid judicial self-government does not mean that internal judicial independence is properly guaranteed.

The Court's recognition of internal judicial independence has thus led to a consistent body of case law that is relevant not only to the post-Communist member states of the Council of Europe but also to its established democracies, such as the Netherlands. Now that the content and relevance of the Court's case law on internal judicial independence is clear, it is time to turn a critical eye to its place within the broader context of the Strasbourg case law on Article 6.

\section{A Critical appraisal of the Court's CASE LAW}

With its recognition of the concept of internal judicial independence, the Strasbourg Court has added a new and important element to its extensive case law on Article 6

proposed the reversal of a case by that same Supreme Court, had constituted the division and had appointed the judge-rapporteur, even though under Lithuanian law he was explicitly prohibited from exerting influence in the exercise of his administrative powers on judges or from otherwise violating their independence).

${ }^{134}$ Note that the Convention does not guarantee 'a right to appointment or promotion in the civil service’ (e.g. ECtHR 28 August 1986, Case No. 9228/80, Glasenapp v Germany, paras. 48-49), including in the judiciary (e.g. ECtHR [DA] 29 June 2004, Case No. 62584/00, Harabin v Slovakia). Nor does the Convention protect a right to a fair competition procedure in a civil service context (ECtHR [DA] 9 October 2012, Case No. 12628/09, Dzhidzheva-Trendafilova v Bulgaria, para. 38). However, when an applicant has on the basis of the domestic law of the Member State an arguable right to promotion, and the domestic courts have the power to examine this claim, Article 6 of the Convention applies and guarantees the applicant a right to a fair trial before the domestic courts (ECtHR 15 September 2015, Case No. 43800/12, Tsanova-Gecheva v Bulgaria, para. 84). 
of the Convention. The Court's case law is often criticised for its lack of conceptual coherence, especially because the Strasbourg Court usually does not distinguish between the two key concepts of Article 6, namely that a tribunal should be 'impartial' as well as 'independent'. ${ }^{135}$ It does so because, according to the Court, these two concepts are difficult to distinguish. ${ }^{136}$ Of course, this bears some truth. Both requirements, after all, serve the same purpose: they are intended to ensure that judges assess the cases assigned to them in an open-minded manner. Nevertheless, the fact that the Court often fails to distinguish between the two concepts inevitably leads to confusion between them. The case law on internal judicial independence adds to this confusion; when violations of internal judicial independence are determined, the Court has often concluded that the tribunal was 'not impartial', instead of 'not independent'. The Court apparently reasons that since the judge on the case was being pressured, the parties to the proceedings were justified in fearing that the court, rather than base its decision on objective arguments, would instead bend to the will of the colleague who was trying to influence him.

Understandably, the Court often sees violations of internal judicial independence through a prism of impartiality, although the requirement of an independent tribunal is also frequently viewed from a separation-of-powers perspective, notably in the scholarly literature on Article 6. There, judicial independence has bearing solely on the relationship between the judiciary on the one hand and the executive and the legislative branch of government on the other. Internal judicial independence does not fit in with this separation-of-powers interpretation of judicial independence because it refers exclusively to the position of the judge within the judiciary.

Although the Court's approach to the concept of 'internal judicial independence' is thus understandable, I nevertheless think that the Court's treatment of the concept as a special form of judicial impartiality should be avoided for three reasons. First, because it is a departure from the way in which the concept is used nowadays in international soft law, compromising the consistency of the Strasbourg case law with standards of international law. Second, because the concept of internal judicial independence is less likely to reach maturity if it is absorbed by the more general case law on impartiality. Its maturation is important because the practical relevance of the concept for the right to a fair trial continues to grow, just as judicial self-government is still on the rise. It would, therefore, be better, and more straightforward, to view the concept of internal judicial independence as part of the requirement of an 'independent' tribunal. Third, and most importantly, conceptual clarity is crucial for the effectiveness and

\footnotetext{
${ }^{135}$ E.g., T. Barkhuysen et al., 'Right to a fair trial', in P. van Dijk et al. (eds.), Theory and Practice of the European Court of Human Rights (Intersentia 2018) p. 599.

${ }^{136}$ See, e.g., Baturlova v Russia, supra n. 23, para. 28.
} 
persuasiveness of the Court's case law and, ultimately, also for the legitimacy of the Strasbourg Court.

Two identical judgments, in both of which a violation of internal judicial independence led the Strasbourg Court to conclude that there was a breach of the Article 6 requirement that a tribunal be 'independent', show how this can be done. First, the Court tries to untangle its own case law on independence and impartiality:

'Independence of the judiciary refers to the necessary individual and institutional independence that are required for impartial decision making. It thus characterises both a state of mind and a set of institutional and operational arrangements. The former is concerned with the judge's impartiality and the latter with defining relations with other bodies, in particular other state powers, and are, sometimes, indivisible'. ${ }^{137}$

The Court thus distinguishes between two types of judicial independence. On the one hand, there is the independence of the individual judge, which the Court defines as a certain 'state of mind' necessary for 'impartial decision making'. This independence of the individual judge relates to the Article 6 requirement that a tribunal should be 'impartial'. The institutional and operational arrangement for impartial decision-making, on the other hand, relates to the Article 6 requirement of an 'independent' tribunal. According to the Strasbourg Court, both independence and impartiality thus aim to enable judges to decide cases impartially, that is: fairly. The way they achieve this goal, however, differs: independence does so by means of legal rules ('institutional and operational arrangements') that define the position of the judge with respect to 'other bodies, in particular other state powers'; impartiality does so by protecting a certain 'state of mind' on the part of the judge.

It should be noted that the Court, in this case, appears to define independence within the meaning of Article 6 exclusively with regard to the position of the individual judge in the state. Unlike the definition of judicial independence one encounters in the literature, however, the Court does not reserve it strictly for the relation between the court and the other two branches of government since it speaks of 'other bodies, in particular other state powers'. Next, the Court states that the requirement of an 'independent' tribunal includes the concept of internal judicial independence. It considers:

'The Court notes that judicial independence also demands that individual judges be free not only from undue influences outside the judiciary, but also from within. This

${ }^{137}$ Khrykin v Russia, supra n. 23, para. 28; Baturlova v Russia, supra n. 23, para. 28. 
internal judicial independence requires that they be free from instructions or pressures from the fellow judges and vis-à-vis their judicial superiors.' ${ }^{138}$

I think that the incorporation of the concept of internal judicial independence into the existing case law on judicial independence should be followed in other cases. It would be helpful if the Court - in the mould of the reasoning in the above-cited case - explicitly redrafted its definition of judicial independence. To this end, the Court should no longer regard judicial independence exclusively in the light of the separation of powers, but also in the light of the independent position of individual judges operating within the state. Defined thus, judicial independence would not only serve as a buffer against the executive and legislative branches but also as a guarantee against the exertion of undue influence on judges by officials within the judicial branch. I tend toward this solution, since the concept of internal judicial independence could remain as it currently is, while allowing a meaningful distinction to be drawn between impartiality (which continues to pertain to an independent state of mind on the part of the judge in relation to the parties to the proceedings and their case) and independence (which then relates to the position of the judge versus governmental officials, in general).

\section{ConClusion}

The Strasbourg Court's recognition of internal judicial independence reflects a fundamental adjustment of the values underlying its case law on Article 6 of the Convention. This recognition is a valuable adjustment of the Court's long-standing separation-of-powers perspective on judicial independence. The Court shows a growing awareness of the importance of the independence of the individual judge, and rightly so: this adjustment is invaluable in times when the judicial selfgovernment model of court governance turns out to have drawbacks of its own.

The consequences of this shift in the Court's case law are most dramatically felt in the formerly Communist countries represented in the Council of Europe; these are so far the only countries condemned for violations of the principle of internal judicial independence. As I have shown using the Netherlands as a case study, however, the new Strasbourg standards may prove problematic also for the established democracies of the Council of Europe.

Thus, the Strasbourg Court's recognition of the concept of internal judicial independence represents a fundamental adjustment to its case law that will bear consequences for all the member states of the Council of Europe. To be fully effective and persuasive, however, the concept of internal judicial independence should be clarified by the Court within the framework of Article 6, as suggested in the previous pages. Only then can the concept of internal judicial independence truly fulfil its purpose: enabling the individual judge to administer justice fairly.

${ }^{138}$ Khrykin v Russia, supra n. 23, para. 29; Baturlova v Russia, supra n. 23, para. 29. 